\title{
Formulation of chikki by using gum Acacia
}

\author{
Surekha Dombe, Md Aleem Zaker and S.P. Deokar
}

\begin{abstract}
Substance frequently called gums are hydrocarbon of high molecular mass that gives viscous solution at low concentration. The most fundamental property of gums is, therefore water solubility and high viscosity in aqueous dispersion. It is very evident that gums have very vast application in pharmaceutical and food industries, as a result of this; there is increase in demand for gums globally. India with divergent food habit is having a number of traditional foods, including sweet products; chikki is one of the popular Indian traditional sweet snacks. It is prepared by mixing roasted groundnuts and other ingredients either with jaggery or sugar. In the present investigation an attempt has been made successfully to assess the physiochemical properties of gum Acacia. Further study has been carried out on the groundnut chikki, by adding the gum in the recipe of groundnut chikki at different levels, and their effects on the sensorial characteristics and physical properties of the groundnut chikki has been studied. From the investigation it is clear that chikki prepared from gum acacia is having good texture, flavour and appearance so the overall acceptability is high. The nutritive value of the chikki prepared from the gums is having high nutritional value in terms of protein content.
\end{abstract}

Key Words : Hydro carbon, Gums, Traditional food, Chikki, Jaggery

How to cite this article : Dombe, Surekha, Zaker, Md. Aleem and Deokar, S.P. (2014). Formulation of chikki by using gum Acacia. Food Sci. Res. J., 5(2): 200202. 